\title{
The Radical Majoritarianism of Rule 23(b)(2)
}

\author{
Myriam Gilles* \& Gary Friedman**
}

The instant Symposium, to which we are delighted to contribute this article, marks the 50th anniversary of the contemporary class action. It also provides a uniquely apt occasion for sharing an insight that we have come to over the past decade-plus of conducting and writing about large and potentially transformative class cases seeking injunctive relief. The insight is this: neither Rule 23 nor its judicial gloss provides coherent principles for determining when and to what extent an injunctive class action may sacrifice the interests of some class members in favor of a greater good.

One often reads that, "because of the group nature of the harm alleged and the broad character of the relief sought," Rule 23(b)(2) classes are necessarily "homogenous and cohesive group[s] with few conflicting interests." "But that truism is debatable; at minimum, it begs the question of what counts as a "conflicting interest." As we have observed elsewhere, "significant injunctive-relief class actions will almost always feature some measure of heterogeneity in the goals and agendas of the constituent class members." 2 How should we account for these divergent interests? Fifty years on, no coherent theory gives us a basis for making these judgments in injunctive class actions.

And we sorely need a theory. Class members often have conflicting positions with respect to the outcome of litigation-especially in

\footnotetext{
* Paul R. Verkuil Research Chair and Professor of Law, Cardozo Law School. Many thanks to David Marcus for thoughtful comments; the paper also benefited greatly from the comments and discussion at the Kansas conference for which it was prepared.

** Attorney at Law. Full disclosure: Mr. Friedman was a lead plaintiffs' counsel in the payment systems antitrust litigation referenced in this article and has continuing interests in those cases.

1. Allison v. Citgo Petroleum Corp., 151 F.3d 402, 413 (5th Cir. 1998); see also David Marcus, Flawed But Noble: Desegregation Litigation and Its Implications for the Modern Class Action, 63 Fla. L. REV. 657, 664 (2011) [hereinafter Marcus, Flawed] ("The fact that a 23(b)(2) class is an actual group that exists in the real world, not some assemblage cobbled together for the sake of expediency, motivates this presumption of cohesion.").

2. Myriam Gilles, Can John Coffee Rescue the Private Attorney General? Lessons from the Credit Card Wars, 83 U. CHI. L. REv. 1001, 1011 (2016); Marcus, Flawed, supra note 1, at 664 ("Conflicts of interest abound in Rule 23(b)(2) suits.").
} 
complex, structural reform cases of the type that Rule 23(b)(2) addresses, and was meant to address. For example, it may be the case that a minority within an injunctive class would prefer to reject the terms of a particular consent decree or settlement, while the majority of class members support the negotiated relief. Is this a disabling conflict? Should we require total homogeneity of class member interests in order to settle the (b)(2) class action and order the injunction? ${ }^{3}$ If not, what is the basis for extinguishing, via a non-opt-out class settlement process, the rights of dissenting members to bring suit challenging defendant's conduct as they see fit? ${ }^{4}$ On the other hand, what level of heterogeneity can the (b)(2) class action accommodate? Should we presume, for starters, that a (b)(2) injunctive class can tolerate more than zero dissenting class members but less than $50 \%$ ? These questions have arisen with great urgency in a number of prominent, recent class actions and, looking back, it is clear that we have lacked any meaningful answers since the inception of the rule.

It is not just the degree of permissible heterogeneity that we need to account for, but the type of class member interests at stake. Professor Bone (another contributor to this Symposium) has suggested that class members' differing "subjective preferences or goals" should not be relevant to the determination of whether a (b)(2) class can be maintained. ${ }^{5}$ As he points out, "[e]ven a civil rights class action can include class members with different preferences about the scope of injunctive relief and different views on the desirability of suing at all." But how do we determine whether class member objections are based on objectively identifiable interests rather than subjective preferences? Is that distinction really coherent? Aren't preferences themselves the product of objective interests filtered through experience? If an AfricanAmerican mother is opposed to a school busing decree because she believes the injunction will undercut efforts to improve the local school, is that a mere preference? Is (b)(2) a license to ignore her interests?

3. Gilles, supra note 2, at 1012 (observing that "if we insist on a truly unitary set of preferences and agendas" among class members, we render (b)(2) class actions uncertifiable).

4. Id. at 1011-12 (raising the concern that ignoring conflicts among class members allows "[s] ettlement terms [to] reflect the preferences of the majority, while releases will snuff out the ability of the minority to pursue its preferred resolutions through litigation"). (2014).

5. Robert G. Bone, The Misguided Search for Class Unity, 82 GEO. WASH. L. REv. 651, 707

6. Id. Elizabeth Chamblee Burch likewise observes that (b)(2) "plaintiffs' opinions about risk, relief, and strategy may differ vastly even though plaintiffs share a similar trait before suing." Elizabeth Chamblee Burch, Aggregation, Community and the Line In Between, 58 U. KAN. L. REV. 889,893 (2010). 
What if this mom is employed by the local school-does her interest graduate from mere preference to objectively identifiable interest?

The accommodation of heterogeneous class member interests within injunctive class actions raises difficult questions. And the framers of Rule 23 did not supply intellectually satisfying answers. ${ }^{7}$ Rule 23(b)(2) was intended by the framers as a powerful legal tool for effectuating racial desegregation in the face of southern intransigence. But it is a misconception that the paradigmatic (b)(2) civil rights cases and their pre-1966 forebears comprised homogeneous classes with unitary interests. On the contrary, intra-class conflicts abounded. ${ }^{8}$ But as Professor David Marcus has explained, the nobility of the civil rights project led the progressive 1966 framers and a generation of courts to sweep those intra-class differences aside in the service of a greater good. ${ }^{9}$ We indulge a fiction - a convenient one to the framers of Rule 23-when we justify the trans-substantive mandatory class action by reference to a "presumption of cohesiveness." 10 That justification runs counter to the historical record, which instead points to a benevolent paternalism that knowingly ignored divergent class member preferences in the service of a greater good.

The residue of indulging a fiction is fog. We are left with no coherent trans-substantive justification for a radical majoritarian device that allows minority interests in litigation to be steamrolled. The civil rights paternalism that accounts for Rule 23(b)(2) ill fits the contemporary injunctive class action, where entrepreneurial counsel bring mandatory class actions "with increasing frequency in employment, antitrust, environmental, [] securities, and other types of class litigation." 11 The moral clarity of the civil rights cases moved the framers of $(b)(2)$ to sweep the problem of divergent class-member preferences under the rug. But moral clarity is not a workable principle. Gestalt judgments as to the greater good are unsatisfying answers to sophisticated class members who question why their interests may be ignored.

7. 7A Charles Alan Wright, et Al., Federal Practice \& Procedure § 1768, at 389-93 ( 3 d ed. 2005) (observing that the framers did not address the "difficult" question of the "level of antagonism or conflict that should preclude class certification").

8. See infra text accompanying notes 64-81 (describing intra-class conflicts in school teacher assignment and busing cases).

9. See Marcus, Flawed, supra note 1, at 661 ("the 1966 authors [of Rule 23(b)(2)] drafted a provision that could help judges ignore or bury ... conflicts" of interest among class members in desegregation cases).

10. Id. at 664 .

11. Herbert B. Newberg, NewBerg On Class Actions 62-66 (2003) (citations omitted). 
Many courts have been dismissive of objections founded on heterogeneous class member preferences and interests, relying upon a "presumption of cohesiveness" derived from the supposedly friction-free civil rights cases. Other courts have refused to certify classes in the face of conflicting class member preferences, balking at a disunity that they suppose - quite wrongly - was absent in the paradigmatic civil rights cases that spawned Rule 23(b)(2). ${ }^{12}$ But either way-whether they are pointing to the desegregation cases to justify a presumption of class member harmony supporting certification, or conversely as hard-to-attain ideals of harmony that justify the rejection of (b)(2) classes-courts generally appear blinded by the civil rights paradigm. Reasoned analysis is in short supply. Aphorisms about the nature of "group rights" and the "indivisible nature of the injunctive remedy" are abundant. ${ }^{13}$

The lack of a principled framework for addressing heterogeneous class member preferences in the context of a mandatory class settlement under Rule 23(b)(2) has injected chaos into some of the most economically significant class actions in U.S. history. Most prominently, in In re Payment Card Interchange Fee and Merchant Discount Antitrust Litigation ("MDL 1720"), ${ }^{14}$ the Second Circuit in June 2016 overturned an antitrust class action settlement that would have reformed credit card industry rules and delivered a record $\$ 7.2$ billion to merchant class members. Objecting merchants-large retailers accounting for roughly $20 \%$ of U.S. transaction volume - argued that the requisite cohesiveness was lacking to certify a settlement class under Rule 23(b)(2) because, they alleged, the injunctive deal foreclosed their ability to seek different and preferable injunctive relief terms. ${ }^{15}$ The proponents of the settlement countered that the injunctive rules changes would necessarily affect all class members, arguing that the only thing "required to proceed as a (b)(2) class is that 'the relief sought must perforce affect the entire class." 16

12. See infra text accompanying notes 98-101 (reviewing decisions relying on cohesiveness inquiry to both grant and deny class certification).

13. See id.

14. In re Payment Card Interchange Fee \& Merch. Disc. Antitrust Litig., 827 F.3d 223 (2d Cir. 2016), cert. denied _ S.Ct. _, 2017 WL 1115037 (Mem) (March 27, 2017).

15. Joint Page-Proof Brief for Objectors-Appellants and Plaintiffs-Appellants (Merchants Appellants' Joint Brief) at 48, In re Payment Card Interchange Fee \& Merch. Disc. Antitrust Litig., 827 F.3d 223, (June 16, 2014).

16. Page-Proof Briefs for Plaintiffs-Appellees at 28, In re Payment Card Interchange Fee \& Merch. Disc. Antitrust Litig., 827 F.3d 223 (Oct. 15, 2014) (quoting Wal-Mart Stores v. Dukes, 131 S. Ct. 2541, 2558 (2011)). 
Faced with this fundamental dispute regarding the extent to which Rule 23(b)(2) may accommodate heterogeneous class member interests, the Second Circuit punted. The appellate panel rejected the settlement on the grounds that merchants who would have no interest in damages for past harms-principally, merchants who do not yet exist-were inadequately represented by class counsel who negotiated both the damages settlement and the injunctive terms. ${ }^{17}$ Only separate counsel for the injunctive class, as distinct from the damages class, could ensure procedural fairness to merchants who are interested in injunctive relief but not damages, according to the Second Circuit's ruling. ${ }^{18}$

The Second Circuit's myopic focus on the relatively trivial issue of future merchants appears designed to shoehorn the case into the comfortable parameters of Amchem Prods., Inc. v. Windsor ${ }^{19}$ and Ortiz v. Fibreboard Corp. ${ }^{20}$ rather than grapple with the difficult issues posed by conflicting class member preferences. Still, one supposes, a renewed settlement will soon enough spawn all the same arguments from the large objectors that their interests are being steamrolled by a mandatory class. And at that point, the MDL 1720 court will presumably confront headlong the legal fog that has shrouded Rule 23(b)(2) since its 1966 inception. Perhaps it will address the question of just when, if ever, the disunity of class member preferences might exceed what Rule 23(b)(2) can bear. ${ }^{21}$

In prior work, we have previously described the "tyranny paradox."22 Where courts allow a broad heterogeneity of preferences to exist within a mandatory class, objectors will complain of a tyranny of the majority. ${ }^{23}$ But where a court tolerates relatively less heterogeneity, insisting upon a unity of class member interests, it sanctions a tyranny of the minority where "a holdout, gadfly, or other outlier can deprive all class members of important relief to which they are entitled, and that they would be unable to obtain in the absence of the class device." 24

7. Merchant Discount, 827 F.3d at 231-34.

18. Id. at 234. ("Unitary representation of separate classes that claim distinct, competing, and conflicting relief create unacceptable incentives for counsel to trade benefits to one class for benefits to the other in order somehow to reach a settlement.").

19. 521 U.S. 591 (1997).

20. 527 U.S. 815 (1999).

21. 827 F.3d at 234 ("We do not decide whether providing [(b)(2)] class members with opt-out rights would be a sufficient 'structural assurance of fair and adequate representation'... to overcome the lack of separate class counsel and representative.") (internal citations omitted).

22. Gilles, supra note 2, at 1011.

23. Id. at $1011-13$.

24. Id. at 1012 . 
There are no simple answers to the tyranny paradox. Distinguishing between the "mere preferences" of dissenting class members, on the one hand, and positions located in "objective" or "structural" member attributes only gets us so far. To be sure, there are cases where class member interests are clearly structural and potentially antithetical to the interests of class counsel, and those cases are tidily addressed under current adequacy of representation doctrine. But once the structural conflicts are accounted for, what then? How should we deal with conflicting class member preferences?

One answer, in theory, would be to alter the rule. But whether there is a compelling case for reform poses a question for a different day. Any such letter to the Advisory Committee is beyond the scope of this modest essay.

If instead the question is how courts should deal with heterogeneity of class member preferences, we believe the answer is rooted in the text and history of Rule 23. As a matter of positive law-of describing what the law is-Rule 23 does take a side on the tyranny paradox. It sides with the tyranny of the majority. Neither the adequacy of representation requirement of (a)(4) nor the judicially grafted "cohesiveness" requirement provides a check on the radical majoritarianism that is coded into the DNA of Rule 23. Of course, there are potential checks against majoritarian overreach, including the fairness requirement of Rule 23(e)(2), or permitting limited injunctive opt-out rights that would not destroy the efficacy of the class relief, but may provide a valve that releases the pressure of the competing tyrannies. This brief essay does not purport to propose a definitive framework for answering the difficult questions posed by the radical majoritarianism of Rule 23(b)(2). Our goal, rather, is to promote a serious examination of mandatory class actions in contemporary practice.

\section{THE HISTORICAL BACKDROP OF RULE 23(B)(2)}

As framed in 1966, the new Rule 23 has been most celebrated for its invention of the Rule 23(b)(3) damages class action - a heady innovation that was carefully designed to preserve individual autonomy and property rights in the face of collectivization, principally by providing notice and opt-out rights in section (c)(2)(B). ${ }^{25}$ But the opt-out damages

25. See David Marcus, The History of the Modern Class Action, Part I: Sturm und Drang, 1953-1980, 90 WASH. U. L. REV. 587, 595-97 (2013); Maureen Carroll, Class Action Myopia, 65 DUKE L.J. 843, 861 (2016) (describing the design of Rule 23(b)(3) as "a new category deliberately created"). 
class was only part of the story. The new rule also built upon existing equity practice allowing for class cases seeking injunctive or declaratory relief, in sections 23(b)(2) and (c)(2)(A). ${ }^{26}$

If the brand new procedures of Rule 23(b)(3) were the product of cool intellectual calculation, the newly framed Rule 23(b)(2) came from the heart. The 1966 framers - progressive-minded lawyers, scholars, and judges, for the most part-conceived (b)(2) as a potent tool for combating segregation. Nothing was more pressing to these men than cementing the ability of civil rights plaintiffs to seek injunctive relief aimed at desegregating institutions and dismantling Jim Crow policies across the South. ${ }^{27}$ As Professor David Marcus has shown, it is difficult to overstate the extent to which desegregation cases were on the minds of the framers in crafting (b)(2). ${ }^{28}$ In fact, the abundant record of contemporaneous correspondence surrounding the drafting of Rule 23 apparently contains no evidence at all that any consideration was given to how Rule 23(b)(2) would function outside of the desegregation context. ${ }^{29}$ And the evidence suggests the framers believed that, inside the desegregation context, substantial departure from traditional doctrinal principles was justified to achieve the ends of social justice.

The traditional rule in equity, and the practice under the 1938 rules of procedure, was that a "true" class action would be entitled to res judicata effect only if the interests and preferences of the class members were perfectly harmonious. ${ }^{30}$ As Marcus explains, the rule "prohibited

26. See 7A Charles Alan Wright, ET Al., Federal Practice AND Procedure, §1751, at 10-17 (3d ed. 2005) (tracing history of the class action from its roots in the Bill of Peace created by the English Court of Chancery to the promulgation of Equity Rule 48, and finally, the adoption of Rule 23); see also StePhen C. YeAzEll, From Medieval Group Litigation to the Modern Class ACTION (1987).

27. See Wal-mart Stores, Inc. v. Dukes, 131 S. Ct. 2541, 2558 (observing that Rule 23(b)(2) "reflects a series of decisions involving challenges to racial discrimination"); see also Marcus, Flawed, supra note 1, at 661 ("Rule 23(b)(2)'s champions ardently supported litigation-driven integration, and they believed class treatment of equal protection claims essential to its success.").

28. Marcus, Flawed, supra note 1, at 703 n.269 (reporting that Kaplan's short-hand for (b)(2) class suits was "the segregation cases," and that other members of the committee referred to this provision as "the integration section").

29. According to committee member John Frank, "the race relations echo of that decade was always in the committee room. If there was [a] single, undoubted goal of the committee, the energizing force which motivated the whole rule, it was the firm determination to create a class action system which could deal with civil rights, and explicitly, segregation. The one part of the rule which was never doubted was (b)(2) and without its high utility, in the spirit of the times, we might well have had no rule at all." John P. Frank, Response to 1996 Circulation of Proposed Rule 23 on Class Actions, in 2 Working Papers Of The Advisory Committee On Civil Rules On Proposed Amendments To Rule 23266 (Administrative Office of the U.S. Courts 1997).

30. Bone, supra note 5, at 665 ("[T] he representative suit in the eighteenth and nineteenth centuries-which was the predecessor of the modern class action-bound class members to the 
class suits that might produce binding judgments to go forward anytime class members might have conflicting preferences for what to do with their rights to sue, provided that these preferences were legally relevant." 31 Professor Bone's work provides numerous examples of representative suits from the 1930's and 40's in which courts determined that individual substantive rights had merged "into a unitary right that attached to the class as a whole." ${ }^{32}$ By the 1950's, a clear line of cases prevented class litigation whenever conflicts of interest among class members was even "conceivable." "33

The early civil rights cases had little trouble negotiating this procedural terrain. Typically, in the period preceding Brown v. Board of Education, these cases sought edicts that a particular institution abolish a specific discriminatory policy-e.g., the de jure policy of a state law school excluding black students. ${ }^{34}$ The pre-Brown cases did not typically

judgment and precluded future litigation only when the class was strongly unified outside the lawsuit."); Bone, supra note 5, at 669 (describing one of the categories created by the 1938 Rule as the "so-called "true class action," where "the character of the right sought to be enforced for or against the class is joint, or common, or secondary"). See also STEPHEN C. YEAZELL, FrOM Medieval Group Litigation to the Modern Class ACTION 175 (1987) (observing that strong class unity was necessary for any representative suit to have preclusive, binding effect).

31. Marcus, Flawed, supra note 1, at 671 (observing that federal courts in the early part of the 20th century "prohibited class suits that might produce binding judgments to go forward anytime class members might have conflicting preferences for what to do with their rights to sue, provided that these preferences were legally relevant"). Going back even further, Professor Yeazell has demonstrated that "early group litigation involved social groups that were already cohesive entities that chose representatives before even appearing in court." Ex parte Assocs. Fin. Servs. Co. of Ala., Inc. 705 So. 2d 836, 838 n.2 (Ala. 1997) (Hooper, J., dissenting) (citing Stephen C. Yeazell, Group Litigation and Social Context: Toward a History of the Class Action, 77 COL. L. REV. 866, 867, 872, 877-78 (1977)), overruled by Ex Parte First Family Fin. Servs., Inc. v. First Family Fin. Servs. Inc., 718 So. 2d 658 (Ala. 1998). See also Diane P. Wood, Adjudicatory Jurisdiction and Class Actions, 62 IND. L. J. 597, 604 n.18 (1987) (providing examples of pure representational cases in equity: Hartford Life Ins. Co. v. Ibs, 237 U.S. 662 (1915); Richmond v. Irons, 121 U.S. 27 (1887); Beatty v. Kurtz, 2 Pet. 566 (1829).

32. Bone, supra note 5, at 666. See also Robert G. Bone, Personal and Impersonal Litigative Forms: Reconceiving the History of Adjudicative Representation, 70 B.U. L. REV. 213, 245-54 and 75-82 (1990) (providing case examples).

33. Range v. Tenn. Burley Tobacco Growers Ass'n., 298 S.W.2d 545, 551 (1955); see also id. ("We think a court of equity should decline to entertain the present action as a class suit for the distinctly different reason that complainants are not in the true sense suing in behalf of other producers.").

34. See, e.g., Mo. ex rel. Gaines v. Canada, 305 U.S. 337 (1938), reh'g denied, 305 U.S. 676 (1939) (concerning a black college graduate challenging the denial of his admission to the University of Missouri Law School on equal protection grounds); Sipuel v. Bd. of Regents, 332 U.S. 631, mandamus denied sub nom., Fisher v. Hurst, 333 U.S. 147 (1948) (same as against University of Oklahoma Law School); Sweatt v. Painter, 339 U.S. 629, reh'g denied, 340 U.S. 846 (1950) (same as against University of Texas Law School). In each of these cases, the Supreme Court held that blacks had been denied rights to equal education in violation of the 14th Amendment, and ordered schools to provide them these benefits. Typically, states responded to these decisions by establishing short-lived black-only schools rather than integrate existing institutions. See, e.g., Mary 
implicate heterogeneous class member preferences, and it is not hard to see why. No black student was forced to apply to law school, after all. The original Brown case was in the same mold. The class plaintiffs sought a simple injunction against the operation of a discriminatory policy. ${ }^{35}$ It seemed reasonably safe to assume class member preferences in favor of such an order were harmonious.

But the segregationist backlash to Brown ushered in the complexities of the modern era. As Professor Marcus explains, crafty southern legislators sought to neuter Brown by enacting state laws under which each pupil was "individually" assigned to a specific school. ${ }^{36}$ Although these "pupil placement" regimes theoretically permitted intrepid individual black students to brave otherwise all-white schools on their own-by challenging their assignments under an administrative procedure and then possibly in court, under Brown-these challenges would presumably be rare. ${ }^{37}$ More importantly, the new regime would insulate the school districts from broad class-wide challenges to their

Ann Connell, The Road to United States v. Fordice: What is the Duty of Public Colleges and Universities in Former De Jure States to Desegregate?, 62 Miss. L.J. 285, $293-94$ (1993) (on remand in Sipuel, the Oklahoma Supreme Court "directed university authorities to either admit Sipuel to the white law school, open a separate one for her, or suspend the white law school until it saw fit to open one for blacks. Consequently, the Oklahoma Board of Regents quickly assigned three white law professors to instruct Sipuel in several roped-off rooms in the state capitol, while it hurriedly began to implement steps to establish a law school for black students at Langston. When Sipuel returned to court to complain that the creation of a one-student, overnight special law school with totally inadequate facilities was an act of defiance of the Court's mandate, the Court announced that the issue of equality of facilities was not properly before it and upheld the right of the State of Oklahoma to create a separate law school for black students. The new law school at Langston was in operation for eighteen months, during which time only one student attended. After the black school closed in 1949, Sipuel was admitted to the University of Oklahoma Law School from which she graduated in 1951.”) (internal citations omitted). Another example is found in cases challenging the policies of various school districts' in paying black teachers less than white teachers for the same work. See, e.g., Alston v. Sch. Bd. of Norfolk, 112 F.2d 992, 995 (4th Cir. 1940) (ordering that black teachers be paid on the same scale as white teachers), cert. denied, 311 U.S. 693 (1940). Here too, a harmonious unity of class member interests can be safely assumed, as all benefited in the same basic way from pay raises.

35. Brown, 349 U.S. 294, 301 (1955) (requiring "District Courts to take such proceedings and enter such orders and decrees consistent with this opinion as are necessary and proper to admit [black students] to public schools on a racially nondiscriminatory basis with all deliberate speed").

36. See Marcus, Flawed, supra note 1, at 684.

37. Id. See also Mark Golub, Remembering Massive Resistance to School Desegregation, 31 LAW \& Hist. REV. 491, 507 (2013) ("Pupil placement laws thus supplied the ostensibly non-racial basis upon which conventionally segregated outcomes in school assignments might be preserved. Additionally, most placement laws specified administrative remedies for parents of students dissatisfied with the school board's initial decision. The grievance procedures further insulated discriminatory treatment from constitutional scrutiny for two reasons. First, drawing out the lengthy appeals process meant that it could take years to exhaust local administrative remedies as required to gain a hearing in federal courts. Second, making the process sufficiently daunting discouraged parents from challenging their school assignments."). 
repackaged Jim Crow policies. ${ }^{38}$ In Briggs v. Elliott, Judge John J. Parker, the segregationists' leading legal light, narrowly interpreted Brown to mean only that schools may not discriminate-and not that they must affirmatively take steps to integrate. ${ }^{39}$ Relying on Briggs, courts across the South upheld the new pupil placement laws. ${ }^{40}$ A pupil who could show discrimination in her placement, they held, would be entitled to relief as to herself alone. The harm was the discriminatory decision made on her placement; it was incurred at the individual level, not the group level. There was, then, clearly no warrant for class relief. ${ }^{41}$

Integrationists on the bench and elsewhere grew frustrated as pupil placement and similar regimes met with considerable success in protecting Jim Crow segregation against court challenge into the early 1960 s. $^{42}$ Professor Marcus makes the compelling case that, as a consequence of this frustration, leading circuit court judges began to read Brown in a way they had not before. ${ }^{43}$ In U.S. v. Jefferson County, Judge

38. Michael Klarman, From Jim Crow to Civil Rights: The Supreme Court and the STRUGGLE FOR RACIAL EQUALITY 330 (2004) ("[T] he patent motive behind pupil placement was to frustrate desegregation by inviting surreptitious consideration of race by school boards and then confounding blacks who were dissatisfied with their placements in a maze of administrative appeals" that further demarcated individual rather than group-based resolutions.).

39. Briggs v. Elliott, 132 F. Supp. 776, 777 (E.D.S.C. 1955). Briggs v. Elliott was one of the consolidated component cases of Brown. On remand after Brown, the Briggs court held that the Supreme Court in Brown "has not decided that the states must mix persons of different races in the schools .... [A]11 that it has decided, is that a state may not deny to any person on account of race the right to attend any school that it maintains." Id. This holding "provided invaluable legal cover to recalcitrant southern officials as they fought to maintain Jim Crow after Brown." Marcus, Flawed, supra note 1 , at 683 .

40. Golub, supra note 37, at 509 ("On Parker's interpretation of Brown, the constitutional prohibition against segregated schools is satisfied by a transition to facially neutral placement criteria or 'freedom of choice' plans, even when doing so results in school attendance patterns indistinguishable from those under Jim Crow. Racial separation itself need not change, only the stated justification for segregation and the techniques by which it is accomplished").

41. See Marcus, Flawed, supra note 1, at 688 ("Individual black students choosing one-by-one to attend white schools, however, would never disassemble the segregation edifice").

42. See, e.g., Shuttlesworth v. Birmingham Bd. of Educ., 162 F. Supp. 372, 384 (N.D. Ala. 1958) (finding pupil placement law constitutionally permissible), aff'd, 358 U.S. 101 (1958); Carson v. Warlick, 238 F.2d 724, 728 (4th Cir. 1956), cert. denied, 353 U.S. 910 (1957) (declining to facially invalidate North Carolina pupil placement law); Calhoun v. Members of the Bd. of Educ., 188 F. Supp. 401, 406 (N.D. Ga. 1959) (same); Beckett v. Sch. Bd. of City of Norfolk, 181 F. Supp. 870, 874 (E.D. Va. 1959) (same). See also Katie R. Eyer, Ideological Drift and the Forgotten History of Intent, 51 HARV. C.R.-C.L. L. REV. 1, 13-14, 13 n. 51 (2016) (observing that "despite their openly segregationist purpose, pupil placement laws proved to be remarkably resistant to constitutional challenge" and citing cases from the late 1950's-mid 1960's in which federal courts upheld these regimes against constitutional challenge).

43. Marcus, Flawed, supra note 1, at 688-90. See, e.g., Bush v. Orleans Parish Sch. Bd., 138 F. Supp. 337, 342 (E.D. La. 1956), aff'd, 242 F.2d 156 (5th Cir. 1957) (A sweeping desegregation order issued by Judge Skelly Wright upon New Orleans schools based on an evolving view of Brown's mandate). 
John Minor Wisdom rejected what he slyly termed the "Briggs dictum" that the Constitution does not require integration but merely forbids segregation - a conception that, Wisdom complained, made it impossible to maintain "class actions suits to desegregate a school system." "In the wake of this landmark decision, the Fifth Circuit and others began to hold that the Fourteenth Amendment does demand integration, requiring school boards "to achieve integrated schools by mixing groups of black and white students together." 45 No longer was the actionable harm of discrimination located at the individual pupil level, as under the pupil placement regimes. ${ }^{46}$ Instead, under Jefferson County and other circuit cases, courts held the actionable harm under Brown is to the group: "Briggs overlooks the fact that Negroes collectively are harmed when the state, by law or custom, operates segregated schools," Judge Wisdom wrote. ${ }^{47}$ "Although the effects of discrimination are felt by each member of the group, and discriminatory practice is directed against the group as a unit and against individuals only as their connection with the group involves the antigroup sanction. [As] a group-wrong, the mode of redress must be group-wide to be adequate." 48

44. U.S. v. Jefferson Cty. Bd. of Educ., 372 F.2d 836, 854 n. 5 (5th Cir. 1966). Judge Wisdom referred to this central precept of the post-Brown jurisprudence as "pure dictum" that had resulted in "frustrating effects" on judicial effort to remedy systemic segregation. Id. at 862. Judge Wisdom wrote that the "Briggs dictum"-which his court and others had restated liberally over the intervening years - "may be explained as a facet of the Fourth Circuit's now abandoned view that Fourteenth Amendment rights are exclusively individual rights and in school cases are to be asserted individually after each plaintiff has exhausted state administrative remedies." Id. at 864. See also Keyes v. Sch. Dist. No. 1, 413 U.S. 189, 200 n.11 (1973) (noting that Briggs' approach had been roundly rejected in earlier decisions).

45. Marcus, Flawed, supra note 1, at 688. See generally JACK BASS, UnLIKELY HerOeS: THE Dramatic Story of the Southern Judges of the Fifth Circuit who Translated the SUPREME COURT'S BROWN DECISION INTO A REVOLUTION FOR EQUALITY (1981).

46. Charles R. Bliss \& C. Talley Wells, Applying Lessons from the Evolution of Brown v. Board of Education to Olmstead: Moving from Gradualism to Immediate, Effective, and Comprehensive Integration, 26 GA. ST. U. L. REV. 705, 714 (2010) (observing that Jefferson revealed "the clear recognition that while discrimination was a violation of individual rights, it was directed at a group").

47. Jefferson Cty., 372 F.2d at 866

48. Id. (quoting Comment, The Class Action Device in Anti-Segregation Cases, 20 U. CHI. L. REV. 577 (1953)). See also Joel Friedman, Desegregating the South: John Minor Wisdom's Role in Enforcing Brown's Mandate, 78 TUL. L. REV. 2207, 2259 (2004) (observing that Judge Wisdom believed that "Brigg's focus on the individual nature of Fourteenth Amendment rights was inconsistent with Brown II's explicit recognition of the right of blacks as a class to a unitary, nonracial system of public education. By requiring states only to provide relief to discrete individuals, the opinion in Briggs permitted, and even encouraged, the perpetuation of a dual, segregated system because it failed to address, let alone cure, the systemic constitutional wrong of legally mandated educational apartheid"); $i d$. ("Wisdom insisted, because the evil perpetrated by de jure segregation was an injury to an entire race, any meaningful, constitutionally appropriate remedy had to address that class-wide wrong."). 
The courts' recognition of an affirmative state duty to achieve integration was surely a momentous development in substantive civil rights law. ${ }^{49}$ But it also had a profound, if less obvious, effect on class action procedure. The traditional equity rule requiring homogeneous class member preferences had been unproblematic when courts were striking down, say, a municipal rule precluding blacks from using certain city parks. But it would be unreasonable to expect unanimity-or anything like it-when shuffling the school assignments of all pupils in the Fort Worth School District, ${ }^{50}$ or busing Memphis pupils out of their home neighborhoods. ${ }^{51}$

Working at the zenith of the civil rights movement, the drafters of Rule 23 understood that the percolating flood of integration cases for which they designed Rule 23(b)(2) would not satisfy the traditional requirement of perfectly harmonious class member preferences. ${ }^{52}$ But they also understood, as Professor Marcus has shown, that "the effective vindication of Fourteenth Amendment rights required systemic integration, or the treatment of black students as groups regardless of their individual preferences." $" 53$ Chief drafter Ben Kaplan thus resisted proposals to import from equity the perfect harmony standard for

49. Green v. Cty. Sch. Bd., 391 U.S. 430, 437-38 (1968). The Supreme Court applied Wisdom's reasoning in Jefferson County on a nationwide basis, holding that school boards were "clearly charged with the affirmative duty to take whatever steps might be necessary to convert to a unitary system in which racial discrimination would be eliminated root and branch." See also Swann v. Charlotte-Mecklenburg Bd. of Ed., 402 U.S. 1, 16 (1971) (demonstrating that the Court continued course, stating that it would "correct, by a balancing of the individual and collective interests, the condition that offends the Constitution").

50. See, e.g., Flax v. Potts, 915 F.2d 155 (5th Cir. 1990) (decades-long desegregation case involving the Fort Worth Independent School District which entailed, among other things, reassignment of students and faculty, extensive cross-town busing, the implementation of a majorityto-minority transfer policy, and the building of new magnet schools).

51. See, e.g., Northcross v. Memphis Bd. of Educ., 302 F.2d 818 (6th Cir. 1962). Memphis schools remained deeply segregated into the 1970 s, when the district judge finally ordered a new plan for cross-town busing of almost 40,000 students-which led to the withdrawal of 29,000 students from the Memphis school system. Daniel Kiel, Exploded Dream: Desegregation in the Memphis City Schools, 26 L. \& INEQUALITY 261, 288 (2008).

52. See, e.g., NAACP v. Button, 371 U.S. 415, 462 (1963) (Harlan, J., dissenting) (describing potential class conflicts in desegregation cases: "it is not impossible that after authorizing action in his behalf, a Negro parent, concerned that a continued frontal attack could result in schools closed for years, might prefer to wait with his fellows a longer time for good-faith efforts by the local school board than is permitted by the centrally determined policy of the NAACP. Or he might see a greater prospect of success through discussions with local school authorities than through the litigation deemed necessary by the [NAACP]"); Robert H. Birkby \& Walter F. Murphy, Interest Group Conflict in the Judicial Arena: The First Amendment and Group Access to the Courts, 42 TEX. L. REV. 1018, 1037 (1964) ("[F]requently occasions might arise in which the choice between an immediate small gain and possible later achievement of a larger aim should at least be put to the plaintiff in whose name the suit was being brought, not decided for him by third parties.").

53. Marcus, Flawed, supra note 1, at 710. 
injunctive cases, and he and Wright likewise eschewed any requirement that the relief must be indivisible, ${ }^{54}$ having learned from the pupil placement regimes and Briggs just how readily an indivisibility requirement could be gamed. ${ }^{55}$

Reasonably enough, the framers evidently believed there was no satisfactory basis for prescribing the level of disunity among class member preferences that a (b)(2) class may accommodate-not without jeopardizing the civil rights class cases that were their focus. ${ }^{56}$ And they apparently regarded that the objective sought in those cases was so clearly correct, so overwhelmingly important, that steamrolling some measure of dissent was a price worth paying. ${ }^{57}$ In all events, the final

54. Committee member John P. Frank expressly proposed to limit mandatory class treatment to cases where "the practical effect of the relief granted ... is to make it impossible or impractical to litigate the matter further[]"-i.e., to cases involving a "unitary course of action in which there is no divisibility." Id. at 700 (alteration in original) (quoting Undated Memorandum from John P. Frank to Benjamin Kaplan, Professor, at 9, microformed on CIS-6310-17 (Jud. Conf. Records, Cong. Info. Serv.)). Kaplan rejected this "indivisibility metric" Marcus has explained, because it would have excluded "race relations cases." Id. at 700 n. 249.

55. Id. at 706. Kaplan and Charles Alan Wright were likewise unpersuaded by the suggestion of Committee member J.P. Frank to leave (b)(2) out of the rule altogether and instead leave the certification of civil rights classes to section (b)(1)(A), on the theory that a defendant would be subjected to "incompatible standards" if a court were to hold "that a school should be segregated as to one applicant but not as to another." Id. Wright predicted that segregationist courts and recalcitrant schools would have a field day with such a doctrine, noting a recent decision where a "decree was entered providing the bus company must transport the three named plaintiffs without discrimination, but it could . . refuse all other Negroes." See Marcus, Flawed, supra note 1, at 706 (alteration in original) (quoting Transcript of Session on Class Actions 13 (Oct. 31, 1963-Nov. 2, 1963), microformed on CIS-7104-53 (Jud. Conf. Records, Cong. Info. Serv.).

56. Id. at 699 (observing that "neither in the extensive memoranda he drafted to lay the legal basis for the new rule nor in any other surviving documentation of his efforts did Kaplan explain why this intrinsic harmony existed in injunctive relief cases"); $i d$. at 709 (noting that the 1966 drafters "gave no explanation ... for why an injunctive relief class judgment could bind absent class members with possibly divergent preferences ...").

57. Members of the advisory committee were not alone in disregarding potential conflict among putative class members. As Derrick Bell recounts in this emblematic story, leading civil rights groups also discounted community preferences that clashed with the goal of full integration:

I was visited by a small group of parents and leaders of the black community [who] needed legal help because the school board had closed the black elementary school in their area even though the school had been built during the 1930's with private funds and was maintained, in part, by the efforts of the black community. Closing of the school necessitated busing black children across the county to another black school. In addition, the community had lost the benefit of the school for a meeting place and community center. The group wanted to sue the school board to have their school reopened. I recall informing the group that both LDF and NAACP had abandoned efforts to make separate schools equal, but if they wished to desegregate the whole school system, we could probably provide legal assistance. The group recognized as well as I did that there were only a few black attorneys in Mississippi who would represent the group, and that those attorneys would represent them only if a civil rights organization provided financial support. Sometime later, the group contacted me and indicated they were ready to go ahead with a school desegregation suit. It was filed in 1963, one of the first in the state. 
text of (b)(2) provided no limiting principle to account for divergent class member preferences regarding injunctive remedies. As written, (b)(2) provides only that the challenged conduct of the defendant must "apply generally to the class, so that final injunctive relief... is appropriate respecting the class as a whole." satisfied in cases where some class members (or even a great many) would prefer (or even greatly prefer) to pursue different (or even opposed) injunctive strategies, or where dissenting class members would prefer to reject proposed settlement terms altogether and preserve individual rights to sue.

In the end, the framers took comfort in the expectation that class member dissent inside the civil rights cases would be rare and muted. In fact, when asked whether he could "imagine including in [a Rule 23(b)(2)] class somebody who specifically objects," chief drafter Ben Kaplan simply answered that he did not "think the cases typically arising under [the provision] would present that problem at all.".59 Kaplan and his colleagues thus rejected all bids to supply a limiting principle to account for divergent member preferences. ${ }^{60}$

Of course, all of this history would be of relatively narrow interest but for the fact that the framers of Rule 23 were insistent that the new rule (b)(2) must provide a trans-substantive rule of civil procedure. This was not obvious or uncontroversial at the time. Committee member John P. Frank, a prominent practitioner, was extremely concerned that the new rule marked an unprecedented intrusion on litigant (or class member) autonomy. When Kaplan nixed the idea of extending opt-out rights to (b)(2) cases, Frank (who was personally quite liberal and had handled important civil rights cases) argued for limiting the reach of (b)(2) to the "race relations" cases. ${ }^{61}$ Needless to say, this proposal went nowhere, and the final Advisory Committee notes are explicit that "Subdivision (b)(2) is not limited to civil-rights cases."62 In the end, Marcus tells us,

\footnotetext{
The Leake County incident was unusual at that time because, in most instances, civil rights lawyers advised black parents of their rights under Brown in situations where there was little or no discussion of alternatives to integration. ... My view then was that a federal suit designed simply to reopen a segregated black school, even if successful, would constitute far less than the full realization of rights to which these parents were entitled under Brown.

Derrick A. Bell, Jr., Serving Two Masters: Integration Ideals and Client Interests in School Desegregation Litigation, 85 YALE L.J. 470, 476 n. 21 (1976).

58. FED. R. CIV. P. 23(b)(2).

59. Marcus, Flawed, supra note 1, at 698 (alteration in original) (internal citations omitted).

60. See id.

61. See id. at 703

62. FED. R. CIV. P. 23(b)(2) advisory committee's notes.
} 
Frank wrote to Kaplan that he had simply "subordinate[d] [his] own doubts' as to Rule 23(b)(2) for political reasons, not because he had come up with some autonomy rationale for mandatory class treatment." For Frank and his progressive brethren, the political imperative of desegregation demanded that any potential intra-class conflicts be swept aside in the service of a greater good.

\section{Disparate Class-Member Preferences Under Rule 23(B)(2)}

In the years following the 1966 inception of Rule 23, courts applied (b)(2) to increasingly complex civil rights issues and institutional reform cases - and, relatedly, to cases that featured ever greater disunity of class member preferences. ${ }^{64}$ For example, beginning in the late 1960s and continuing for decades, courts grappled with class action remedies designed to integrate the faculties and staffs of public schools. ${ }^{65}$ These cases generated tremendous difficulties and implicated hugely divergent class member interests. ${ }^{66}$ Many black teachers in historically segregated districts were absolutely mortified at the prospect of teaching white students. ${ }^{67}$ Others were put to great hardship in having to travel from their home school zones. ${ }^{68}$ But the injuries wrought by the school districts' discriminatory policies were common to the class in each case, and the injunctions affected each class as a whole. Widely divergent class member preferences, then, were no bar to the certification of

63. Marcus, Flawed, supra note 1 at 702 (alterations in original) (internal citations omitted).

64. As Deborah Rhode notes, "schisms" between class members commonly "surface during settlement or remedial deliberations." Deborah Rhode, Class Conflicts in Class Actions, 34 STAN. L. REV. 1183, 1188 (1982). Class members may have been in general agreement about the harm, but lack "a shared conviction about the appropriate remedy." Id. at 1189. "However, once it becomes clear that some relief will be forthcoming, factions emerge." Id.

65. See, e.g., Green v. Cty. Sch. Bd., 391 U.S. 430, 435 (1968) (requiring disestablishment of continued segregation in faculty assignment).

66. See, e.g., U.S. v. Jefferson Cty. Bd. of Ed., 372 F.2d 836, 892 (1966) ("The most difficult problem in the desegregation process is the integration of faculties."); Kelley v. Altheimer, 378 F.2d 483, 493 (8th Cir. 1967) ("[T]o eliminate segregation of the faculty ... may well be the most difficult problem in the desegregation process. ...").

67. Wendy Parker, Desegregating Teachers, 86 Wash. U. L. REV. 1, 12-13 n. 48 (2008) ("[B]lack teachers ... wondered too, after years with all-black charges, how well they would teach in integrated schools and whether white students and parents would accord them proper respect.") (alterations in original).

68. Id. 
classes under Rule $23(\mathrm{~b})(2)^{69}$-no matter how powerfully those preferences were expressed. ${ }^{70}$

School busing cases presented the same issues. In 1970's Boston, for example, violent clashes over court-ordered busing plans quickly exposed fissures among members of the black community over the goals of desegregation litigation. ${ }^{71}$ Derrick Bell recounted that, while some class members remained fully committed to the ideal of "total desegregation," others grew deeply "ambivalent about the busing plans" and sought instead to upgrade existing black schools to improve educational opportunities and retain minority control. ${ }^{72}$ Across the country-in San Francisco, ${ }^{73}$ Detroit,$~^{74}$ Atlanta, ${ }^{75}$ and Dallas ${ }^{76}$ - classmember opposition to remedial busing plans emerged and grew more forceful over time. And while some civil rights lawyers acknowledged these splintering interests, most were fearful (just as the drafters of (b)(2) had been) that surrendering to claims of individualized student

69. See Hobson v. Hansen, 269 F. Supp. 401, 502 (D.D.C. 1967) ("But if any truth is axiomatic, it is that the Negro students' equal protection rights to an integrated faculty cannot be undermined or thwarted by the racially induced preferences of the teachers ...").

70. Parker, supra note 67, at 15 (discussing massive lay-offs of black teachers as a result of Brown); see also Sabrina Hope King, The Limited Presence of African-American Teachers, 63 REV. EDUC. RES. 115, 135 (1993) ("[B]etween 1954 and 1965, as an immediate consequence of desegregation, 38,000 African-American teachers lost their positions as teachers and administrators in 17 states.").

71. Morgan v. Hennigan, 379 F. Supp. 410, 482 (D. Mass 1974), aff'd sub nom. Morgan v. Kerrigan, 509 F.2d 580 (1st Cir. 1974), cert. denied, 421 U.S. 963 (1975). See also Matthew Delmont, The Lasting Legacy of the Boston Busing Crisis, THE ATLANTIC (Mar. 29, 2016), https://www.theatlantic.com/politics/archive/2016/03/the-boston-busing-crisis-was-never-intendedto-work/474264/ (detailing violent protests in response to school busing plan).

72. Bell, supra note 57 at 482-89 (describing the varied interests and positions on school desegregation and busing within the black community); see also Rhode, supra note 64, at 1189 ("Constituencies that support integration in principle have disputed its value in particular settings where extended bus rides, racial tension, or white flight seem likely concomitants of judicial redistricting. Some minority administrators, teachers, and parental organizations have opposed interdistrict remedies that would close minority schools or dilute minority control.").

73. See id. at $483 \mathrm{n} .41$ (describing desegregation litigation in San Francisco where the district judge observed during a hearing with the parties that "[t]here's something new that's coming along .... There [is] beginning to emerge a demand on the part of large segments of minority groups, particularly among the blacks, that they run their own schools and they have black schools") (alterations in original) (internal citations omitted).

74. See, e.g., Bradley v. Milliken, 402 F. Supp. 1096, 1101 (E.D. Mich. 1975) (observing, of plaintiffs' proposed busing plan, that "rigid and inflexible desegregation plans too often neglect to treat school children as individuals, instead treating them as pigmented pawns to be shuffled about and counted solely to achieve an abstraction called 'racial mix"').

75. Bell, supra note 57, at 485 ("[T] school integration and those of local blacks who favored plans oriented toward improving educational quality occurred in Atlanta.").

76. See, e.g., Tasby v. Wright, 520 F. Supp. 683, 733 (N.D. Tex. 1981) (addressing minority parents' opposition to busing children below grade four in Dallas desegregation suit). 
preferences threatened to defeat their "single-minded commitment" to integration. $^{77}$ In Bell's view, the integration-or-bust mission of the prominent civil rights groups "obviate[d] any need to determine whether a continued policy of maximum racial balance conform[ed] with the wishes of even a minority of the class."

In Keyes v. School Dist. No. $1,^{79}$ emblematic of the era, the Supreme Court upheld a plan to integrate Denver area schools by various means, including long-distance, cross-town busing. In dissent, Justice Powell fretted that, "[i]n the commendable national concern for alleviating public school segregation, courts may have overlooked the fact that the rights and interests of children affected by a desegregation program also are entitled to consideration." 80 For Justice Powell, missing from the Court's analysis was any consideration of the individualized preferences of black students - for example, some wished not to be "on a bus for a substantial part of the day," or expose themselves to the "genuine element of danger" of attending a faraway, all-white school. ${ }^{81}$ Nor did the Court reflect upon, in Justice Powell's view, the desire among some black parents that their "children attend community schools near home" and receive instruction by black teachers who would serve as models of achievement. $^{82}$

It is telling that the basis for Justice Powell's dissent, as well as the separate dissent of Justice Rehnquist, had nothing to do with Rule 23-

77. Bell, supra note 57, at 492 n.64 (quoting NAACP General Counsel Nathaniel Jones: "It would be absurd to expect that each and every black person should be polled before a lawsuit is filed, or a plan of desegregation is proposed. Certainly, school boards, who resist these suits, do not poll their patrons on their views before shaping a position").

78. Id. at 492. Bell continues:

This position represents an extraordinary view of the lawyer's role. Not only does it assume a perpetual retainer authorizing a lifelong effort to obtain racially balanced schools. It also fails to reflect any significant change in representational policy from a decade ago, when virtually all blacks assumed that integration was the best means of achieving a quality education for black children, to the present time, when many black parents are disenchanted with the educational results of integration.

Id. See also Rhode, supra note 64, at 1211 (discussing civil rights attorneys focus on "maximum integration... [that] led them to ignore a shift in priorities among many black parents from racial balance to quality education").

79. 413 U.S. 189 (1973).

80. Id. at 247 (Powell, J., dissenting) (quoting Swann v. Charlotte-Mecklenburg Bd. of Ed., 402 U.S. 1, 15-16 (1971): "[a] school desegregation case does not differ fundamentally from other cases involving the framing of equitable remedies to repair the denial of a constitutional right. The task is to correct, by a balancing of the individual and collective interests, the condition that offends the Constitution"). Id. at 239.

81. Id. at 238 n.19 (citing Comment, School Desegregation After Swann: A Theory of Government Responsibility, 39 U. CHI. L. REV. 421, 422, 443 (1972)).

82. Id. at 245 . 
after all, the Rule makes no provision for denying class treatment based on heterogeneous preferences. Instead, the dissenters would have restored something akin to the substantive civil rights law doctrine of Briggs, rejecting any basis for affirmative decrees mandating particular levels of pupil integration (and, in the process, obviating any question of divergent class member preferences). ${ }^{83}$ Most explicit was Justice Rehnquist's dissent, channeling Judge Parker's distinction between desegregation and integration:

To require that a genuinely 'dual' system be disestablished, in the sense that the assignment of a child to a particular school is not made to depend on his race is one thing. To require that school boards affirmatively undertake to achieve racial mixing in schools [...] is quite obviously something else. ${ }^{84}$

Throughout, the courts' unflinching application of Rule 23(b)(2) to complex civil rights cases implicating heterogeneous class member preferences was faithful to the intent behind the rule. In drafting (b)(2), the framers had eschewed limitations upon the degree of permissible disunity in class member preferences. And so, courts confronting the complex civil rights cases of the 1970s and beyond had little trouble applying the rule as written. If the preferences of some teachers, students or families got steamrolled by class injunctions in the teacher integration and busing cases, that was just the inevitable result of the rule. ${ }^{85}$

Over the past several decades, of course, the substantive context of Rule 23(b)(2) cases has broadened, moving beyond the initial focus on desegregation and into a wider realm of consumer, antitrust, employment and other cases. ${ }^{86}$ In part, this expansion has tracked the spread of legal

83. Id. at 250-51 ("There is nothing in the Constitution, its history, or - until recently-in the jurisprudence of this Court that mandates the employment of forced transportation of young and teenage children to achieve a single interest, as important as that interest may be.").

84. Id. at 258.

85. Class conflicts were generally ignored in other (b)(2) contexts as well. See, e.g., Rhode, supra note 64, at 1190 (offering examples of "comparable cleaves" among class members in other institutional reform contexts, such as cases seeking to enjoin unlawful employment discrimination, unconstitutional prison conditions, and discriminatory disability policies).

86. See Baby Neal v. Casey, 43 F.3rd 48, 59 (3d Cir. 1994) (observing that while the (b)(2) class may have been "designed specifically for civil rights cases seeking broad declaratory or injunctive relief for a numerous and often unascertainable or amorphous class of persons" it is now employed in a variety of non-civil rights contexts, including consumer, antitrust, employment, and toxic harm classes) (quoting NEWBERG AND CONTE § 4.11, at 4-39); see also Linda S. Mullenix, No Exit: Mandatory Class Actions in the New Millennium and the Blurring of Categorical Imperatives, 2003 U. CHI. LEGAL F. 177, 180 (2003) ("[T]he mandatory class in the twenty-first century bears only remote resemblance to the archetypal illustrations in the Advisory Committee's 1966 Note."). 
activism outward, from its civil rights core, into other settings. ${ }^{87}$ But equally, in our view, the expansion has been a byproduct of the advent of entrepreneurial class action lawyers, ${ }^{88}$ profit-seeking actors for whom injunctive relief and the threat of injunctive relief are useful tools - both to lend a sort of social-justice sheen to their actions (and this is not a cynical point: the social-justice wrapping of entrepreneurial litigation often benefits class members in courts and public opinion) and to lever greater monetary compensation for class members and counsel. Class actions in the employment, consumer and antitrust areas routinely feature claims for injunctive relief running alongside claims for damages, and they routinely settle for substantial damages and insubstantial injunctive relief. $^{89}$

All these developments - plus the fact that class action settlements, nowadays, feature broad and carefully negotiated releases ${ }^{90}$ - put pressure on a mandatory class action device that was not built to give vent to the interests of dissenting class members. For one, the sheer sprawl of class practice into complex areas, like antitrust cases with the potential to reform entire industries, virtually ensured that the heterogeneity of class member preferences would be amplified. ${ }^{91}$ And for another, the deployment of the double-barreled injunctive-anddamages class device in the hands of entrepreneurial lawyers virtually ensured greater steamrolling of dissenter interests and preferences. ${ }^{92}$ The steamroller was always there-we saw that in the civil rights cases of the 1970s, for instance - but now there was a powerful engine attached to it:

87. See, e.g., Sean Farhang, The Litigation State: Public Regulation and Private LAWSUITS IN THE U.S. 69 (2010) (describing 1970's rise in litigation brought by issue-oriented citizens groups with pro-regulatory agendas, such as environmental, civil rights, and consumer protection organizations).

88. See generally JOHN COFFEe, ENTREPRENEURIAL Litigation: IT'S Rise, FALL AND FUTURE (Harvard 2015).

89. See Linda S. Mullenix, Getting to Shutts, 46 U. KAN. L. REV. 727, 742 (1998) (observing that in the last decade "more and more class litigants have attempted to resolve aggregate litigation through mandatory, binding settlement classes that incorporate monetary damage claims or release monetary damage claims").

90. See, e.g., Susan P. Koniak, How Like a Winter? The Plight of Absent Class Members Denied Adequate Representation, 79 Notre DAME L. ReV. 1787, 1851-52 (2004) ('It is no secret and no sin that the aim of defendants in ... class actions ... is 'global peace,' an end to litigation on the matter," which is secured by broad releases against future litigation.).

91. See, e.g., Gilles, supra note 2, at 1020-21 (describing proposed injunctive settlements in contemporary, complex cases that promise "substantial benefit[s] for a strong majority of class members, but that a minority ... oppose[] on the ground that they could do better for themselves if left to pursue their own individual injunctive claims").

92. See Mullenix, supra note 86, at 217 (“[T] he mandatory nature of the 23(b)(2) part of the class could serve as a bar to the pursuit of future claims, which preclusive effect might not be ameliorated by the 23(b)(3) presence of an opt-out right."). 
the drive to maximize class member compensation (and, of course, attorneys' fees as well).

But through all these developments, the doctrinal architecture of Rule 23(b)(2) has remained unscathed. The radical majoritarianism that lies at the heart of the mandatory class action stands unbent by 50 years of practice.

To be sure, there have been significant doctrinal developments under Rule 23(b)(2) over the years, but none that directly implicate the issue of warring class member preferences. Most significant was the rise and fall of the so-called "hybrid" class action, where plaintiffs (mostly in employment cases) sought to certify classes under (b)(2) for both traditional injunctive relief and some "incidental" form of monetary relief styled to appear as an equitable remedy-e.g., back-pay under Title VII, or restitution or disgorgement. ${ }^{93}$ Before they were rendered extinct by Wal-mart v. Dukes, ${ }^{94}$ the hybrid cases raised the issue of whether (b)(2) might permit opt-out procedures. ${ }^{95}$ Because the hybrids implicated individual claims for money (however those claims might be denominated), several pre-Dukes courts held that individual class members must, as a matter of due process, have the option to request exclusion from the (b)(2) class. $^{96}$ Importantly, it appears that nearly every case approving (b)(2) opt-outs has implicated individual monetary interests. $^{97}$

The other noteworthy doctrinal development under (b)(2) has been the judicial grafting of a "cohesiveness" requirement onto the text of the rule. The cohesiveness requirement imports into (b)(2) the superiority and manageability requirements of 23(b)(3) - and arguably predominance as well. ${ }^{98}$ The key point is that the cohesiveness

93. See, e.g., Allison v. Citgo Petroleum Corp., 151 F.3d 402, 423 (5th Cir. 1998). See also 42 U.S.C. $\S 2000 \mathrm{e}-5(\mathrm{~g})$.

94. 565 U.S. 338 (2011).

95. Gilles, supra note 2, at 1023 ("The pre- Wal-Mart Stores case law is useless here. To the extent that opt-outs have been allowed under Rule 23(b)(2), it has primarily been in the sort of 'hybrid' cases that Wal-Mart Stores abolished.") (citations omitted).

96. See, e.g., Eubanks v. Billington, 110 F.3d 87, 94 (D.C. Cir. 1997) ("[T]he language of Rule 23 is sufficiently flexible to afford district courts discretion to grant opt-out rights in (b)(1) and (b)(2) class actions."); Holmes v. Continental Can Co., 706 F.2d 1144, 1154-55 (11th Cir. 1983) (describing how claims for monetary relief may dissolve the homogeneity that forms the basis of the (b)(2) class, necessitating an opportunity for members to opt out).

97. See, e.g., Johnson v. Meriter Health Servs. Emp. Ret. Plan, 702 F.3d 364, 371 (7th Cir. 2012); McReynolds v. Richards-Cantave, 588 F.3d 790, 800 (2d Cir. 2009); Jefferson v. Ingersoll Int'l. Inc., 195 F.3d 894, 898 (7th Cir. 1999); Billington, 110 F.3d at 94; Penson v. Terminal Transp. Co., Inc., 634 F.2d 989, 993 (5th Cir. 1981); Newsome v. Up-to-Date Laundry, Inc., 219 F.R.D. 356, 364 (D. Md. 2004).

98. See, e.g., Donovan v. Philip Morris USA, Inc., 268 F.R.D. 1, 11 (D. Mass. 2010) 
requirement provides a bulwark against the litigation of individual issues in a (b)(2) class. "Rule 23(b)(2)," in other words, "includes an implicit 'cohesiveness' requirement, which precludes certification when individual issues abound." Manageability is the concern. Here again, as with the issue of opt-outs in hybrid cases, the doctrinal development does not purport to address the problem of how to treat conflicting class member preferences. ${ }^{100}$

For the party seeking to argue that its litigation preferences are unfairly impinged by a mandatory class action, the cases affirming a (b)(2) cohesiveness requirement and the hybrid cases supporting a (b)(2)

(observing that the cohesiveness requirement "imported the (b)(3) predominance requirement into the (b)(2) realm"); Amgen Inc. v. Conn. Ret. Plans \& Tr. Funds, 133 S. Ct. 1184, 1204 (2013) (observing that cohesiveness under (b)(2) overlaps significantly with the predominance inquiry under (b)(3), as both seek to ensure that "individual reliance questions will not overwhelm the questions common to the class"); Amchem Prods., Inc. v. Windsor, 521 U.S. 591, 623 (holding the "predominance inquiry tests whether proposed classes are sufficiently cohesive to warrant adjudication by representation"). See also David Marcus, The Public Interest Class Action, 104 GEO. L.J. 777, 788-89 (2016) (observing that some courts have found that "cohesiveness amounted to a predominance inquiry," but observing that, overall, cohesiveness is "a test with no anchor in the text of the rule").

99. See, e.g., Thompson v. Am. Tobacco Co., Inc., 189 F.R.D. 544, 557 (D. Minn. 1999). The Third Circuit first established the cohesiveness requirement reasoning that "courts must determine whether a proposed (b)(2) class implicates individual issues" because (1) a "suit could become unmanageable ... if significant individual issues were to arise consistently" and (2) "it would be unjust to bind absent class members to a negative decision where the class representatives' claims present different individual issues than the claims of the absent members present." Barnes v. Am. Tobacco Co., 161 F.3d 127, 143 (3d Cir. 1998),. See also In re St. Jude Med., Inc., 425 F.3d 1116, 1121-22 (8th Cir. 2005) ("Although Rule 23(b)(2) contains no predominance or superiority requirements, class claims thereunder still must be cohesive."); Shook v. Bd. of Cty. Comm'rs of Cty. of El Paso, 543 F.3d 597, 604 (10th Cir. 2008) ("A class action may not be certified under Rule 23(b)(2) if relief specifically tailored to each class member would be necessary to correct the allegedly wrongful conduct of the defendant.") (quoting 5 Moore's Fed. Prac. § 23.43(2)(b) at 23195); M.D. ex rel. Stukenberg v. Perry, 675 F.3d 832, 846 (5th Cir. 2012) (holding class not certifiable under (b)(2) because "individual issues overwhelm cohesiveness" and class members are "injured by a smorgasbord of day-to-day, case-by-case operational failures . . . as opposed to the State's implementation of any specific policy uniformly affecting - and injuring - each child"); M.A. ex rel. E.S. v. Newark Pub. Sch., 2009 U.S. Dist. LEXIS 114660, at *49-50 (D.N.J. Dec. 7 , 2009) (observing "claims to recover compensatory education fail (b)(2)'s cohesiveness requirement" where they involve "individual inquiries [that] ... threaten to overwhelm the action and render it unmanageable."); Donovan, 268 F.R.D. at 11 (observing the cohesiveness requirement "imported the (b)(3) predominance requirement into the (b)(2) realm"); Parko v. Shell Oil Co., 739 F.3d 1083, 1085 (7th Cir. 2014) (noting cohesiveness "goes to the efficiency of a class action as an alternative to individual suits"); Lightfood v. District of Columbia, 273 F.R.D. 314, 329 n.12 (D.D.C. 2011) (clarifying that "absent sufficient cohesiveness, actions would inevitably become so unmanageable that the primary purpose of the class action device-i.e., advancing judicial economy and efficiency through class-wide treatment-would be destroyed").

100. Burch, supra note 6, at 982 (2010) ("Because (b)(2) class actions do not require opt-out opportunities, assuming cohesion allays judges' qualms about due-process concerns such as personal notice and the ability to exit .... Consequently, [courts] presum[e] that class members' interests are cohesive, even when that presumption is fictitious.”). 
opt-out right present a sort of fool's gold: they glitter, but fail to deliver any analytic value. An extra-statutory "cohesiveness" requirement is a tempting place for class objectors to look for protections against majoritarian overreach. But as we have discussed, cohesiveness is really just shorthand for manageability. And hybrid cases like Eubanks v. Billington provide tempting bases on which to argue that courts may broadly allow opt-outs from (b)(2) classes. ${ }^{101}$ But those cases only ever allowed opt-outs to seek monetary relief-a doctrinal stream that has been fully dammed by Dukes. Still, we should expect to hear these arguments from (b)(2) class members who complain that their interests are being ignored by class settlements. And indeed, these arguments were front and center in the recent payment card cases, as we will discuss in Part III.

Finally, what about the doctrinal developments under the adequate representation requirement of Rule 23(a)(4)? Doesn't that robust body of law provide a basis for addressing warring class member preferences? Here again, the answer is no.

In Amchem Prods., Inc. v. Windsor, the Court held that adequate representation was lacking where the class representatives, who had all been injured by exposure to asbestos, entered a settlement agreement that prejudiced the interests of future claimants, for whom asbestos-related injuries had not yet manifested. ${ }^{102}$ The conflict, according to the Court, was acute: "[f]or the currently injured, the critical goal is generous immediate payments. That goal tugs against the interest of exposureonly plaintiffs in ensuring an ample, inflation-protected fund for the future." 103

Following Amchem, the authors of the ALI's Principles of the Law of Aggregate Litigation, termed these sorts of divergent interests - where proposed settlements shortchanged as-yet-uninjured claimants, who lacked separate representation- "structural conflicts."104 The

101. 110 F.3d at 94. See also infra text accompanying notes 88-89.

102. 521 U.S. 591 (1997). The conflicts in Amchem were significant. Most prominently, the plaintiffs' attorneys were representatives of individuals claiming current injury, but because defendants would not settle without a guarantee against future claims, counsel "endeavored to represent the interests of the anticipated future claimants, although those lawyers then had no attorney-client relationship with such claimants." Id. at 601. Further, the nine named plaintiffs all claimed existing injury, no subclasses were created, and the proposed settlement provided a payment schedule for different types of asbestos-related disease with no adjustment for inflation. Finally, numerous claims - such as fear of future harm and medical monitoring, as well as all punitive damages - were released in the settlement. Id. at 602-04.

103. Id. at 626.

104. PrinCiPles of the LAW OF AgGRegate Litigation, section 2.07(a)(1) (2010) (“(a) As necessary conditions to the aggregate treatment of related claims by way of a class action, the court 
differences between the already-injured members' interests and the interests of the future claimants are "structural," in the sense that they are objectively determined; they are functions of how the class members are situated. These differences arise from objective, ex ante-observable distinctions, and not from any idiosyncratic strategies or preferences. ${ }^{105}$ Accordingly, post-Amchem courts faced with adequacy challenges seek to "ferret out" "whether there are 'structural' conflicts within a proposed class that make it improper for class counsel to represent them all.",106

No doubt, the divide between structural conflicts, on the one hand, and conflicting preferences, on the other, is porous at the margin. ${ }^{107}$ One could argue that preferences themselves are the product of objectively determinable interests, as processed by experience. But in practice, the distinction has not proven difficult for courts to apply. ${ }^{108}$ It does not appear, in fact, that the concept of "structural conflict" has strayed far beyond the paradigm of the future claimant. ${ }^{109}$ And even within the

shall (1) determine that there are no structural conflicts of interest."). See also Reporters' Notes cmt. d ("The casting of subsection (a)(1) in terms of 'structural conflicts of interest' is designed to lend greater precision to the loyalty inquiry in connection with class actions, an inquiry historically phrased in terms of adequate representation.").

105. See, e.g., Georgine v. Amchem Prods., Inc., 83 F.3d 610, 631 (3d Cir. 1996) (holding Rule 23(a)(4) demands adequate "structural protections to assure that differently situated plaintiffs negotiate for their own unique interests"); Ortiz v. Fireboard Corp., 527 U.S. 815, 831-32 (1999) (reversing class certification on adequacy grounds where "the District Court took no steps at the outset to ensure that the potentially conflicting interests of easily identifiable categories of claimants be protected"); Valley Drug Co. v. Geneva Pharm., Inc., 350 F.3d 1181, 1189 (11th Cir. 2003) (finding "the named representatives cannot 'vigorously prosecute the interests of the class through qualified counsel' because their interests are actually or potentially antagonistic to, or in conflict with, the interests and objectives of other class members"); Dewey v. Volkswagen Aktiengesellschaft, 681 F.3d 170, 184 (3d Cir. 2012) (quoting Valley Drug Co., 350 F.3d at 1189) ("A fundamental conflict exists where some [class] members claim to have been harmed by the same conduct that benefitted other members of the class.").

106. Alan B. Morrison, Improving the Class Action Settlement Process: Little Things Mean a Lot, 79 GeO. WASH. L. REV. 428, 439-40 (2011); see also Steven D. Marcus, Note, Resegregation and Non-party Preclusion, 90 N.Y.U. L. REV. 2118, 2137 (2015) ("After Amchem, the focus for those seeking to challenge class settlement shifted to ferreting out every possible conflict between class members."); In re Visa Check/MasterMoney Antitrust Litig., 280 F.3d 124, 145 (2d Cir. 2001) ("The adequacy requirement 'is designed to ferret out' such conflicts of interest 'and to ensure that the putative named plaintiff has the incentive to represent the claims of the class vigorously."').

107. See Gooch v. Life Inv'rs Ins. Co. of Am., 672 F.3d 402, 430 (“'Identity' of interests is 'certainly' not required. But something stronger than '[s]hared interests' is necessary in the event that a class representative's interests only minimally overlap with class members' interests. The proper test lies between these two extremes.") (alteration in original) (internal citations omitted).

108. See Linda S. Mullenix, Taking Adequacy Seriously: The Inadequate Assessment of Adequacy in Litigation and Settlement Classes, 57 VAND. L. REV. 1687, 1698-99, 1703 (2004) (arguing that, in practice, courts "routinely, reflexively, and presumptively certify proposed class counsel as adequate").

109. Cases addressing (a)(4) conflict outside the context of future claimants are sparse. See, e.g., Williams v. City of Phila., 270 F.R.D. 208, 216 (E.D. Pa. 2010) (summarizing that in this prison 
context of settlements that differentially affect future claimants, courts have generally declined to find (a)(4) conflicts from the fact that "representative plaintiffs derive less utility from protections for future claims than those who have only future claims." 110 In the absence of a disabling structural conflict, the fact that "not all members of the class may seek or desire the same relief, or may otherwise have disparate interests, will not render a class definition overly broad or defective or bar the certifying of a class action seeking injunctive and declaratory relief." 111

So where does that leave us? Our thesis is that the framers of Rule 23 , operating out of benevolent paternalism and unable to foresee the expansion of (b)(2) class action practice into the commercial realms, designed a mandatory class device that -it turns out-will tend to run roughshod over the interests of dissenting class members, unless the minority's interests are themselves a function of structural, ex anteobservable attributes. Intra-class tensions arising from this regime have predictably been amplified by the growth of contemporary entrepreneurial class action practice. High-stakes entrepreneurial cases with the capacity to produce structural reform bring the radical

conditions case, the defendant challenged adequacy on the grounds some inmates want to be transferred to less crowded facilities, while others "may wish to remain ... to be close to friends and family"). See also Samuel Issacharoff \& Robert Klonoff, The Public Value of Settlement, 78 FORDHAM L. REV. 1177, 1187 n.48 (2009) (listing class action challenges grounded in adequacy that do not directly implicate the interests of current vs. future class members).

110. Dewey, 681 F.3d 170, 186 (clarifying that "each class member naturally derives different amounts of utility from any class-wide settlement. An older ... plaintiff, for example, might value a front-loaded settlement more than other members of the class. A coupon-clipping representative plaintiff may derive more utility from a coupon-based settlement than other members of the class. To hold that these differing valuations by themselves render the representative plaintiff inadequate would all but eviscerate the class action device"); Gooch, 672 F.3d at 428 ("[D]ifferently weighted interests" among class members "are not detrimental" to application for class certification "[b]ecause few people are ever identically situated;" indeed, "it is easy to paint an image of the class representative's interests as peripherally antagonistic to the class. That depiction does not make the plaintiff an inadequate representative.").

111. Gooch, 672 F.3d at 429 (quoting NewBerg On Class Actions, § 3.23); In re FedEx Ground Package Sys., Inc., Emp. Practices Litig., 273 F.R.D. 424, 438 (N.D. Ind. 2008) (permitting a class-wide challenge to FedEx's practice of selectively categorizing employees as "contractors," despite the fact that some employees categorized as contractors might prefer that categorization due to the "favorable relationship" it allows them to cultivate with the company); Vaccarino v. Midland Nat'l Life Ins. Co., 2013 WL 3200500 (C.D. Cal. June 17, 2013) ("An unlawful charge is an unlawful charge," which "could not [possibly] give rise to intra-class conflicts" even if some class members may have preferred to pay the charge for whatever reason.). See also Samuel Issacharoff \& Richard A. Nagareda, Class Settlements Under Attack, 156 U. PA. L. Rev. 1649, 1684 (2008) (noting that the differences in the class "that matter are those that give rise to a significant potential for negotiation on behalf of an undifferentiated class to skew in some predictable way the design of class-settlement terms in favor of one or another subgroup for reasons unrelated to evaluation of the relevant claims"). 
majoritarian design of Rule 23(b)(2) into particularly stark relief. And no case better showcases these issues than the ongoing Payment Card Interchange litigation, which we discuss in Part III.

\section{THE PAYMENT CARD INTERCHANGE CASE AND THE MANDATORY CLASS}

If Payment Card Interchange did not exist, a law professor would have had to create it as a stylized vehicle for exploring the issues surrounding the mandatory class action in cases featuring heterogeneous class member interests. Among other areas, the case compels the observer to consider: (i) the limits of the adequacy of representation requirement; (ii) the application of the "cohesiveness" doctrine; (iii) the possibility of injunctive opt-out rights in injunctive cases; and (iv) the role of the Rule 23(e) fairness requirement in constraining the tyranny of the majority. We will briefly address each after providing some background.

\section{A. Background}

In Payment Card Interchange, a putative class representing all U.S. credit-card-accepting merchants brought claims against the Visa and MasterCard networks and their top member banks, alleging the swipe fees that merchants incur each time they process a card transaction are inflated by defendants' violations of the antitrust laws. In particular, the merchants challenged several of Visa and MasterCard's network rules. The first related to the rules under which the networks and their member banks centrally set the so-called "interchange rates" that determine the swipe fees each merchant pays. In the lawsuit, the merchants attacked this "Interchange Rule" as collusive price fixing. ${ }^{112}$ Another claim challenged the "No Surcharge Rules"-the network rules that prevent merchants from passing along to their customers the swipe fees they incur-via a discrete surcharge levied on each transaction. ${ }^{113}$ And the lawsuit challenged other network rules as well, including the "Honor All Cards Rule," which prohibits merchants from declining specific Visa or

112. Merchant Discount, 827 F.3d at 228 ("Plaintiffs allege that these Visa and MasterCard network rules, working in tandem, allow the issuing banks to impose an artificially inflated interchange fee that merchants have little choice but to accept.").

113. Id. at 229 ("The most consequential relief afforded the (b)(2) class was the ability to surcharge Visa- and MasterCard-branded credit cards at both the brand and product levels. That is, a merchant could increase the price of a good at the point of sale if a consumer presents (for example) a Visa card instead of cash, or a Visa rewards card instead of a Visa card that yields no rewards."). 
MasterCard-branded cards based on the identity of the issuing bank or other features. ${ }^{114}$

After nearly a decade of litigation, the class and the defendants reached a settlement that provided for the richest payout ever in an antitrust class action-roughly $\$ 7.25$ billion in cash. ${ }^{115}$ On the injunctive side, the deal provided for the rescission of the "No-Surcharge Rules," but did not purport to alter the Interchange "Rules or the Honor All Cards Rules." And the settlement contained broad release terms, under which merchants would release their claims under all three rules. ${ }^{117}$ The settlement provided for separate-but-overlapping classes under both Rule 23(b)(3), for damages, and (b)(2), a mandatory class for injunctive relief. A merchant electing to opt out of the (b)(3) class to seek individual damages would still be bound to the terms of the (b)(2) release, and would of course still get the benefits of the injunctive relief. $^{118}$

The settlement was a controversial one. Objecting merchants launched a nationwide "Stop The Settlement" campaign in industry and media channels. In all, several thousand merchants, and many of the largest U.S. merchants, signed on to one or more of the filed objections, representing $19 \%$ of U.S. card transaction volume in the aggregate. ${ }^{19}$ The objectors' primary complaint was with the injunctive relief providing the ability to impose credit card surcharges. For these class members, this injunctive relief was not sufficiently valuable to justify providing a broad release, under which the defendants would remain free to maintain their Interchange and Honor All Cards Rules. ${ }^{120}$ In short, the

114. Id. at 228 ("The argument is that the honor-all-cards rule forces merchants to accept all Visa and MasterCard credit cards (few merchants can afford to accept none of them).").

115. See In re Payment Card Interchange Fee and Merch. Disc. Antitrust Litig., 986 F. Supp. 2d 207, 213-14 (E.D.N.Y. 2013) (approving settlement that provided for "[t]he creation of two cash funds totaling up to an estimated $\$ 7.25$ billion (before reductions for opt-outs)"); see also Christie Smythe, Visa, MasterCard \$7.25 Billion Fee Deal Wins Approval, BloOMBERG (Nov. 9, 2012).

116. Payment Card Interchange, 986 F. Supp. 2d at 213-14 (approving injunctive settlement providing for "Visa and Mastercard rule modifications to permit merchants to surcharge on Visa- or MasterCard-branded credit card transactions at both the brand and product levels").

117. Payment Card Interchange, 827 F.3d at 230 ("[P]laintiffs are bound by a release that waives any claims they would have against the defendants for: all of the conduct challenged in the operative complaint, all other policies and practices (concerning credit card transactions) that were in place as of November 27, 2012, and any substantially similar practices they adopt in the future.").

118. Id. at 229 (" $[\mathrm{M}]$ embers of the first class (which receives money damages in the settlement) could opt out, but members of the second, forward-looking class (which receives only injunctive relief) could not.").

119. Payment Card Interchange, 986 F. Supp. 2d 207, 223 (E.D.N.Y. 2013); see also Brief on Behalf of Appellant 7-Eleven et al., 12-4671 Doc. No. 983 at 18.

120. The idea behind allowing merchants to impose surcharges to help cover the swipe fees 
nub of the attack on the settlement was the warring preferences of class members.

\section{B. Adequacy of Representation}

In the Payment Card Interchange settlement, the district court approved a dual-class structure consisting of a (b)(3) damages class and a mandatory (b)(2) injunctive class, with one set of lawyers representing all class members. ${ }^{121}$ Dual-class structures of this sort have become commonplace in cases seeking both damages and injunctive relief-and for good reason. ${ }^{122}$ The only alternative is to have a unitary (b)(3) class for all claims, ${ }^{123}$ leaving class members free to opt out with their various idiosyncratic (and possibly conflicting) injunctive claims intact. ${ }^{124}$ Such a regime would all but preclude class actions seeking both damages and injunctive relief against a defendant's across-the-board practices. ${ }^{125}$ The dual-class structure, meanwhile, gives parties the freedom to negotiate with many variables in play-including damages, injunctive terms, and the terms of releases. Subject to the constraints of class counsel's fiduciary obligations and the substantive fairness requirement of Rule 23(e), the dual-class structure allows a defendant to condition the payment of money damages upon the receipt of an airtight release of future injunctive claims. And, in theory, the dual-class structure allows for claims and elements of relief to be traded off against one another, including damages and injunctive elements-much the same way that a

they incur is that this will induce card networks to drop their interchange rates. If a network's rates are too high, in a world without no-surcharge rules, merchants are able to impose surcharges on that network's cards, incentivizing cardholders to use other cards that are not surcharged at the point of sale.

121. 986 F. Supp. 2d 207 (E.D.N.Y. 2013).

122. See, e.g., Ebert v. General Mills, Inc., 823 F.3d 472, 480 (8th Cir. 2016) (describing dualclasses as "an available approach that is gaining ground in class action suits").

123. Another alternative is to seek monetary damages under (b)(2) - but this option is no longer available $\mathrm{n}$ the wake of the Court's decision in Wal-mart v. Dukes. See supra text accompanying notes 94-97.

124. Gilles, supra note 2, at 1023 n.90 ("Indeed, courts have often granted injunctive relief in the context of Rule 23(b)(3) claims, at least when equitable and monetary damages are both sought. And when this occurs, opt-outs from the Rule 23(b)(3) class are free to seek individual injunctive relief.").

125. In fact, a dual-class structure is unavoidable - and a unitary (b)(3) is untenable - if various opt-outs might seek conflicting forms of injunctive relief against the defendant. Rule 23(b)(1)(A) provides for a mandatory class in cases where the different injunctions sought "would establish incompatible standards of conduct" for the defendant. In practice, of course, (b)(2) prevents multiple potentially conflicting injunctions whether or not the defendant can meet the demanding "would establish incompatible standards of conduct" standard. 
lawyer representing an individual client might trade off claims and elements of relief in settlement negotiations.

The Second Circuit decision in Payment Card Interchange raises the question of whether this broad freedom to negotiate is a feature or a bug of the dual-class system. To the court, it was reason enough to reverse the settlement that one set of lawyers represented both the damages class under (b)(3) and the injunctive (b)(2) class and so had incentives to trade off injunctive relief for damages. ${ }^{126}$ The membership of the two classes was largely overlapping - all operating merchants at the time of settlement had live claims for damages and injunctive relief-but the overlap was not total. ${ }^{127}$ The (b)(3) class included merchants who had gone out of business, and the (b)(2) class would bind merchants who do not yet exist - that is, future merchants would be bound by the release and would benefit from the injunction. ${ }^{128}$

The Second Circuit was careful to base its (a)(4) analysis on structural considerations-namely, the structure of the dual-class approach itself. The court was especially careful, in a legislative sort of way, to identify the conditions under which it will find a dual-class structure offends Rule 23(a)(4): "when the (b)(2) and (b)(3) classes do not have independent counsel, seek distinct relief, have nonoverlapping membership, and (importantly) are certified as settlementonly." 229 Of course, settlement-only certification is true in most class cases nowadays. ${ }^{130}$ So the Second Circuit test really comes down to whether there are any non-overlapping members. If there are even a handful, the panel decision tells us, a structural conflict requires "structural protection"-specifically, division of the class into "homogenous subclasses under Rule 23(c)(4)(B), with separate representation to eliminate conflicting interests of counsel."

126. 827 F.3d at 233 ("[T] conflicts and absence of incentive required a sufficient 'structural assurance of fair and adequate representation,' but none was provided.") (internal citations omitted).

127. Id. at 235 (discussing the "partial overlap of merchants" belonging to both the (b)(2) and (b)(3) classes).

128. Id. (predicting that "[o]ver time, the initial overlap will be reduced, and the gap between the interests of the (b)(3) and (b)(2) classes will continue to widen" as some merchants fail and others come into being).

129. Id.

130. See William B. Rubenstein, 2 NeWBerg ON Class ACtions $\S 4: 77$ (West 5th ed. 2012 \& Supp. 2016) (observing that a "stock device" is the settlement class action where "the parties may simultaneously submit to the court both a motion for class certification and a motion to approve a class action settlement."). See also Dukes, 565 U.S. 338 (2011); In re Hydrogen Peroxide Antitrust Litig., 552 F.3d 305 (3d Cir. 2008).

131. 827 F.3d at 231 (quoting Ortiz, 527 U.S. at 856). 
The merits or demerits of the Payment Card Interchange decision are not our focus here. ${ }^{132}$ The point, rather, is the treatment of heterogeneous preferences - an issue that the Second Circuit decision simply defers until it is presented by a structurally homogenous class. Instead of resolving any issues of warring class-member preferences, the panel decision just creates a new issue of warring subclass-member preferences. Within the new subclass, the same issues will persist: some members will very much want the surcharging relief, while others will want to hold out for better or different terms, or just to hold on to their releases.

Suppose that, in the wake of the Second Circuit's decision, a separately represented injunctive class were to seek approval of the same injunctive relief and release terms as before. What would be the result? The decision suggests that the panel could find yet another structural conflict and, once again, require additional subclassing, and so on-as still-narrower subclasses present the same issues over and over. ${ }^{133}$ For example, the court was sympathetic to the objectors' argument that many merchants cannot derive value from the surcharge relief, either because they are located in a state that bans credit-card surcharges by law, or because the merchant accepts American Express and is limited in its ability to surcharge under Amex rules:

132. That said, in our view, the Second Circuit's ruling clearly suffers from a flawed reading of Amchem and Ortiz. Those cases involved two sets of mutually exclusive and antagonistic claims. Every dollar that went from a limited asbestos fund to a presently-injured plaintiff was a dollar lost to a future claimant. That zero-sum antagonism was the whole predicate for the rule of those cases. In Payment Card, by contrast, there is no zero-sum equation at all; there is no antagonism between the claims. Indeed, all of the representative class plaintiffs have both claims.

133. 827 F.3d at 238 ("[A]ny merchant that operates in New York, California, or Texas (among other states that ban surcharging), or accepts American Express (whose network rules prohibit surcharging and include a most-favored nation clause) ... [c] an get no advantage from the principal relief their counsel bargained for them."). This argument harkens back to an older approach, rejected by the 1966 framers, that no self-appointed representative could sue on behalf of a class of rights holders and obtain a preclusive judgment without class members opting in. See, e.g., Hansberry v. Lee, 311 U.S. 32, 44 (1940) ("It is one thing to say that some members of a class may represent other members in a litigation where the sole and common interest of the class in the litigation is either to assert a common right or to challenge an asserted obligation. [] It is quite another to hold that all those who are free alternatively either to assert rights or to challenge them are of a single class, so that any group merely because it is of the class so constituted, may be deemed adequately to represent any others of the class in litigating their interests in either alternative. Such a selection of representatives for purposes of litigation, whose substantial interests are not necessarily or even probably the same as those whom they are deemed to represent, does not afford that protection to absent parties which due process requires.") (internal citations omitted). We thank David Marcus for pointing this out. 
[many] merchants in the (b)(2) class are either legally or commercially unable to obtain incremental benefit from the primary relief negotiated for them by their counsel .... This is not a matter of certain merchants (e.g., those based in New York and those that accept American Express) arguing that class counsel did not bargain for their preferred form of relief .... ${ }^{134}$

Does this suggest that, if the new (b)(2) subclass were to propose the same surcharging relief, the court would demand homogenous, separately represented subclasses comprised of merchants who operate in the states with no-surcharge statutes, or who accept American Express? It seems to. And the result is a Russian matryoshka doll of an adequacy inquiry, with nested subclasses and sub-subclasses. When a subclass presents warring preferences, the Second Circuit approach suggests the court (with the aid of objectors) might find some structural hook for narrowing the class, in an attempt to shoehorn the case into the mold of Ortiz and Amchem, where it can declare that "structural defects in this class action created a fundamental conflict." ${ }^{\text {"135 }}$ But what if the real source of disharmony flows not from any structural differences at all? The objectors in Payment Card Interchange, after all, are not "unable" to benefit from the negotiated relief (e.g., because their business is limited to a state that bans surcharging). They are national merchants-e.g., Home Depot, 7-Eleven, Target-who derive varying levels of utility from the negotiated relief based on a host of factors.

The matryoshka model is ill suited for homogenizing the levels of utility that different class members can be expected to enjoy from a given set of negotiated reforms. Even a subclass comprised of merchants with operations located solely in one of the states with no-surcharge laws could quite rationally favor the same deal terms allowing for credit-card surcharging. After all, the state anti-surcharge statutes have been the ongoing subject of constitutional challenges for years-and were recently held likely unconstitutional by the Supreme Court. ${ }^{136}$ And in any event, the denizens of a nested subclass of merchants in a no-

\footnotetext{
134. Id. at 238 (emphasis added).

135. 827 F.3d at 236 .

136. Expressions Hair Design et al. v. Schneiderman, _ S. Ct. _ (March 29, 2017) (holding that the New York ban on credit card surcharges implicates commercial speech and remanding to the Second Circuit). In the wake of Expressions, the Supreme Court denied certiorari in Dana's R.R. Supply v. Attorney Gen., Fla, 807 F.3d 1235, 1249 (11th Cir. 2015), thus solidifying the Eleventh Circuit's determination that the Florida statute is unconstitutional. The Court also remanded to the Fifth Circuit its decision in Rowell v. Pettijohn, 816 F.3d 73, 80 (5th Cir. 2016) for reconsideration of the Texas statutory ban on credit-card surcharges (striking down Florida ban on credit-card surcharges). Gary Friedman, co-author of this essay, initiated these merchant attacks on the state anti-surcharge statutes along with Gupta Wessler LLP.
} 
surcharge state (if there are any left) might rationally expect that the threat of surcharging in the remaining forty-eight (or however many) states will cause the nationwide interchange rates to drop, thus benefiting even the merchants in the last remaining matryoshka doll. And such a deal would especially make sense if counsel for the nested subclass shares the view that the consideration for the negotiated relief-namely, the release of certain other hypothetical claims (e.g., on the Honor All Cards and Interchange Rules) is a relatively trivial price to pay. ${ }^{137}$

In the end, (a)(4) adequacy analysis merely shuffles the problem around, from a class level to a subclass level. The same merchants are likely to have the same substantive objections to the same deal, down the road. If we are looking at ways to address those objections, we must look elsewhere.

\section{The Cohesiveness Requirement}

In Payment Card Interchange the objectors argued that "the far-flung mandatory (b)(2) class lacked sufficient cohesion" because the injunctive relief in the settlement "had different value to different class members." 138 They complained that settlement has "bound together, in a mandatory (b)(2) class, millions of diverse merchants with conflicting interests in both the one claim on which they were granted relief [i.e., the surcharging claim] and the vastly broader collection of claims that the settlement resolved." "139 In short, they argued, "[i]f individual class members would want to litigate and redress their claims in different ways [] then those claims are not suitable for (b)(2) treatment."

But as Professor Marcus's historical work makes clear, (b)(2) has always accommodated diverse plaintiffs with conflicting interests who might wish to litigate and redress their claims in different ways. ${ }^{141}$ That was the innovation of (b)(2) and its improvement upon the state of the art under equity practice, where complete harmony of interests was required. As we discussed above, the cohesiveness requirement that courts have

137. 827 F.3d at 238 ("It may be argued that the claims of the (b)(2) class are weak and can command no benefit in settlement.").

138. Merchant Appellant's Joint Brief at 21, 24, In re Payment Card Interchange Fee \& Merch. Disc. Antitrust Litig., 986 F. Supp. 2d 207 (E.D.N.Y. 2013) (No. 12-4671), 2014 WL 7335990.

139. Id. at 46 .

140. Id. at 49 .

141. Marcus, Flawed, supra note 1 at 710 (observing that "the effective vindication of Fourteenth Amendment rights required systemic integration, or the treatment of black students as groups regardless of their individual preferences"). 
located in Rule 23(b)(2) is nothing more than a stand-in for the manageability and superiority requirements that are explicit in (b)(3).

In the end, there is clearly no warrant for implying a requirement under (b)(2) that class member interests be homogenous or identical. Instead, courts have recognized that "each class member naturally derives different amounts of utility from any class-wide settlement"142 and "differently weighted interests are not detrimental" to class certification "[b]ecause few people are ever identically situated."143

If there is a doctrinal constraint on heterogeneous class member preferences, we must keep looking.

\section{Rule 23(e)'s Fairness Inquiry}

To whatever extent, there is at least some check against majoritarian overreach in the requirement of Rule 23(e)(2) that any settlement must be found "fair, reasonable, and adequate" if it purports to bind class members. ${ }^{144}$ In fact, courts look at the "reaction of the class to the settlement" as a key factor in their tests for assessing whether (e)(2) has been met. ${ }^{145}$ But the standard for finding favorable class member reaction under (e)(2) is easily met. The Second Circuit, for instance, has held "that an otherwise fair settlement should not be deemed unfair because of opposition by thirty-six percent of the total class." Moreover, Rule 23(e) only applies to settlements, not trials. A settlement with deeply unpopular terms can be rejected, under (e)(2), and class members will then be free to pursue alternative, preferred remedies. But those same deeply unpopular terms may be obtained at trial, where (e)(2) has no application, and the class members will then be barred from pursuing their preferred alternative actions as a matter of res judicata.

\footnotetext{
142. Dewey v. Volkswagen Aktiengesellschaft, 681 F.3d 170, 186 (3d Cir. 2012).

143. Gooch v. Life Inv'rs Ins. Co. of Am., 672 F.3d 402, 429 (6th Cir. 2012).

144. Joel A. v. Giuliani, 218 F.3d 132, 138 (2d Cir. 2000) (citations omitted).

145. Id. (citing to the factors announced in City of Detroit v. Grinnell Corp., 495 F.2d 448 (2d Cir. 1974)). Other circuits apply similar multi-factor tests, or follow Grinnell itself. Molski v. Gleich, 318 F.3d 937, 953 (9th Cir. 2003); In re General Motors Corp. Pick-Up Truck Fuel Tank Prods. Liab. Litig., 55 F.3d 768, 785 (3d Cir. 1995) (applying Grinnell factors); Gottlieb v. Wiles, 11 F.3d 1004, 1014 (10th Cir. 1993); In re Compact Disc Minimum Advertised Price Antitrust Litig., 216 F.R.D. 197, 206-07 (D. Me. 2003) (district courts in First Circuit apply Grinnell factors).

146. In re Initial Pub. Offering Sec. Litig., 671 F. Supp. 2d 467, 485 (S.D.N.Y. 2009) (following "Second Circuit['s] ... guidance as to what percentage of the class must object before a settlement would be rendered unfair...") (citing Grant v. Bethlehem Steel Corp., 823 F.2d 20, 24 (2d Cir. 1987) ("We perceive no reason why a settlement cannot be considered fair despite opposition from... significantly less than half of the class.")).
} 
In Payment Card Interchange, the Second Circuit could have- and frankly, should have - analyzed the relative values of the injunctive relief and the (b)(2) release under the rubric of Rule 23(e), and not under 23(a)(4). Rule 23(e) calls for a merits review, with facts on the table. The analysis under (a)(4) is entirely different: an ex ante inquiry to see if, based on the structural positioning of the parties and counsel, conflict is likely. It is an odd heuristic to apply a formal ex ante lens when realworld information is available. The Second Circuit, in essence, held that it was unacceptably likely that unitary counsel could have traded injunctive relief for money to the detriment of class members. But the relevant question should have been whether there was any detrimental trade-off in the real world. Rule 23(e) cuts through the formalism and examines the actual deal. Substantive evaluation of the value of the release under 23(e) would have required some analysis of the claims being released. Implicit in the panel opinion is that there was value in the released claims. A Rule 23(e) inquiry, by contrast, would not turn on bald presumptions. If a deal is fair and adequate, it will be approved under Rule 23(e). If not, then it will not.

\section{E. 23(b)(2) Opt-Outs}

Another potential check against majoritarian overreach is opt-out rights. In the Payment Card Interchange case, Judge Jacobs's panel decision swept aside the opt-out question, clarifying that "[w]e do not decide whether providing [(b)(2)] class members with opt-out rights would be a sufficient 'structural assurance of fair and adequate representation'... to overcome the lack of separate class counsel and representative." 147 Presumably, though, opt-out rights would obviate any concern about the settlement that an objector might have. ${ }^{148}$ A different question is whether the court may allow opt-outs under (b)(2).

Courts have only ever allowed opt-outs under (b)(2) in the context of "hybrid" cases seeking nominally equitable forms of monetary relief-a line of case law that was emphatically overruled in Wal-Mart Stores, Inc. v. Dukes. ${ }^{149}$ Whether courts possess discretion to allow opt-outs in

147. 827 F.3d 223, 234 (2d Cir. 2016) (internal citations omitted).

148. After all, the opt-out right obviates the due process objections in damages cases under Shutts. It is hard to see how an objecting plaintiff would be injured if it were given the ability to assert its own injunctive claims in an opt-out action, or to simply retain the right to sue and not be bound by the $(b)(2)$ release.

149. See text accompanying notes 94-97. Note, in Wal-mart itself, the Court observed that (b)(2) "provides no opportunity for . . class members to opt out . ." 564 U.S. 338, 362 (2011).. 
injunctive class actions post-Dukes is an open question. ${ }^{150}$ Justice Scalia's majority opinion in that case observed "(b)(2) does not require that class members be given ... opt-out rights, presumably because it is thought (rightly or wrongly) ... that depriving people of their right to sue in [a mandatory class] complies with the Due Process Clause." ${ }^{\prime 151}$ Still, a court could presumably allow for opt-outs if the settling parties agreed. ${ }^{152}$ And there is authority - albeit arising in a limited fund case under (b)(1) - for allowing an opt-out from an otherwise mandatory class action in exceptional circumstances under the catchall authority provided in Rule 23(d)(1)(E). ${ }^{153}$

In any event, if courts can direct opt-outs under (b)(2), it seems obvious that the injunctive opt-out right should be limited to cases where the bid for individual injunctive relief would be compatible with the class relief. ${ }^{154}$ Where the would-be opt-out relief would thwart the class relief in practical effect-where individual litigations would "substantially impair or impede" the "ability" of the "other members not parties to the individual adjudications" "to protect their interests"-Rule 23(b)(1)(B) would bar opt-outs by its terms. Still, where this compatibility test is met, allowing for carefully circumscribed injunctive opt-out rights may, in some cases, provide a valve to alleviate the intra-class pressure created by conflicting remedial preferences. In the case of 1720 , where objectors argued only that injunctive relief was insufficient consideration for a

150. McReynolds v Richards-Cantave, 588 F3d 790, 800 (2d Cir. 2009) (allowing a Rule 23(b)(2) plaintiff who objected to the settlement to opt out, stating that " $[t]$ he right of a class member to opt-out in Rule 23(b)(1) and (b)(2) actions is not obvious on the face of the rule; however, "the language of Rule 23 is sufficiently flexible to afford district courts discretion to grant opt-out rights in (b)(1) and (b)(2) class actions"') (quoting Eubanks v. Billington, 110 F.3d 87, 94 (D.C. Cir. 1997).

151. 564 U.S. at 363.

152. See, e.g., Newberg, supra note 130 at $\S 4: 36$ (observing that while opt-outs are not required in Rule $23(\mathrm{~b})(2)$ class actions, "they are discretionary, may be permitted, and have been employed").

153. Rule 23(d)(1)(E) endows district courts with discretion to "issue orders that ... deal with similar procedural matters." FED. R. CIV. P. 23(d)(1)(E). This discretion is meant to facilitate "the fair and efficient conduct of the action." FED. R. CIV. P. 23, Advisory Committee Notes to the 1966 Amendments. See also County of Suffolk v. Long Island Lighting Co., 907 F.2d 1295, 1305 (2d Cir. 1990). In that limited fund case, the court allowed Suffolk County to opt out and seek full recovery because, unlike the other plaintiffs and "at great expense, Suffolk litigated its claims and obtained a jury verdict in its favor" and, further, "permitting Suffolk to opt out," would not "substantially impair or impede the class members' ability to protect their interests." (Brackets omitted) (citing FED. R. CIV. P. 23(b)(1)(B)).

154. See, e.g., Ryan C. Williams, Due Process, Class Action Opt Outs, and the Right Not to Sue, 115 Colum. L. ReV. 599, 652 (2015) (suggesting that "the determination of whether opt-out rights are required should turn ... on the relationship between the individual claims of absent class members and the scope of the defendant's remedial obligation" rather than on a "sharp distinction between equitable claims and monetary claims"). 
broad release - and not that any objector had individual injunctive claims it wished to pursue on its own - the compatibility rationale for injunctive opt-outs is lacking. ${ }^{155}$

\section{CONCLUSION}

Among the questions raised by mandatory class actions seeking consequential injunctive relief is how to account for divergent preferences and agendas among the various members of the represented class. Virtually all significant injunctive-relief class actions will feature some measure of heterogeneity in the goals and agendas of the constituent class members. Do we simply steamroll over these oppositional viewpoints in order to achieve a settlement in service of the greater good-as the framers of the 1966 Rule appear to have contemplated in the narrow context of civil rights cases? Or do we try to determine just how much heterogeneity due process can comfortably accommodate within a mandatory, non-opt-out class? If we decide to engage in the latter exercise, what analytic tools should we employRule 23 (a)(4) adequacy, principles of "cohesion," Rule 23(e) fairness factors? Or perhaps we should sanction limited injunctive opt-outsallowing those who do not wish to be bound by a settlement to state their intent to seek individual relief or "vindicate a real interest" that is separate from but "consistent with the class relief"? 156 Fifty years after the amendments to 1966 , these questions - so fundamental to the fair operation of Rule 23(b)(2) - remain unanswered.

155. Gilles, supra note 2, at 1025 n.96.

156. Gilles, supra note 2, at 1026. 